\title{
Effectiveness of Use of Technical Skill Assessment Instruments to Increase Web Programming Competency
}

\author{
$1^{\text {st }}$ Rafiqa Durotul Maknuna \\ Department of Vocational Education \\ Universitas Negeri Malang \\ E-mail: rfqdm@yahoo.com
}

\author{
$2^{\text {nd }}$ Amat Mukhadis \\ Faculty of engineering \\ Universitas Negeri Malang \\ Malang, Indonesian \\ mukhadis_s@yahoo.com
}

\author{
$3^{\text {rd }}$ Sy aad Pathmantara \\ Department of Electrical Engineering \\ Faculty of Engineering \\ Universitas Negeri Malang \\ Malang, Indonesia \\ syaad_um@yahoo.co.id
}

\begin{abstract}
This study aims to: (1) the development of a prototype model of student skills assessment instruments on the web programming practicum; (2) a prototype feasibility assessment assessment instrument in the skills skill of SMK students on a web programming practice; and (3). techniques on web programming techniques. This research is a research and development of Research and Development $(R \& D)$ method that adapted 4-D development research model. The subjects of the product trial were teachers and students of class X SMKN 6 Malang, SMKN 11 Malang, and SMKN 3 Malang which required 90 students for trials and 10 students for a limited trial. The product eligibility was validated by 2 evaluation experts and 1 practitioner. Skills tests are performed by comparing posttest scores between groups using technical assessment tools with groups not using technical skills assessment instruments. Data comparison with an interview and questionnaire Data were analyzed descriptively quantitative. The results of the research indicate that: (1) has produced a technical skill assessment instrument developed manually and supplemented by instructions for use, scoring guidelines, student worksheets, basic, practical work), and assessment questions and rubrics. (2) the resulting product is feasible to be used for practical learning process based on expert validation, limited testing, and field trials, while for product feasibility the average validation is $95,14 \%$ and cronbach alpha value 0,75 ; and (3) an effective web programming skill assessment tool improves student competence.
\end{abstract}

Keywords- Assessment Instruments, Technical Skills, Web Programming

\section{INTRODUCTION}

Assessment has an important role in the learning process. The benefit of the assessment is to know the extent to which students can understand a material that has been taught by the teacher. Assessment is also used as a reference to see the level of success or effectiveness of teachers in learning. According to
Azim \& Khan [1], assessment is a conventional activity conducted in schools on a day-to-day basis. Assessment is a helpful process in developing student learning. The assessment provides an opportunity for teachers to review their own teaching in improving student learning. According to Gaytan \& McEwen [2], assessment is an important way to respond to student accountability. The educator should establish the objectives of the assessment, the criteria being measured, and the results of the assessment. The main purpose of the assessment is to monitor student learning, improve the academic quality of the program, and improve teaching and learning. Thus, it can be concluded that assessment in the field of education is an activity undertaken by educators and learners to provide information used as feedback to modify learning and teaching activities with the aim of monitoring student learning outcomes, improving program quality, and improving the quality of learning.

According to Hofstein \& Lunetta [3], the activity of assessing the competence of knowledge and skills can be done in a lab in the laboratory. Assessment of knowledge competence can be done by written test, whereas skill judgment is not effective if done by a written test.

According to Firman [4], on practical activities required skills test. With skills tests, student learning outcomes that reflect the competence of skills can be revealed, and Wiscons in Education Association Council [5] asserting that students must demonstrate skills and competencies that have been mastered by using performance appraisals. Based on these definitions, it can be concluded that technicall skill assessment is developed to test students' ability in demonstrating knowledge and skills according to the criteria specified.

Based on the findings in the field note that technicall skill assessment on the psychomotor aspect which is a technique for assessing the skills of students is still not done much by the 
teacher. According to Iskandar [6], states that assessments made by educators generally emphasize more on the as sessment of the cognitive domain. This happens because educators lack understanding of skilled technicall judgments on the psychomotor aspect. According to Susila [7], some obstacles faced by teachers in assessing student performance are the guidance of scoring in the instrument is not clear so difficult to use, the components considered difficult to observe so tends to be ignored,and the instruments used do not meet the requirements of validity and reliability so there is a tendency to give too high value or vice versa. The result of the preliminary study shows that the as ses sment of technical skill as pect on web programming practice has not been done optimally. As sessment is only done with unstructured observation, without the use of instruments, and is limited to only a few skill aspects. Assessment becomes poor because the skills aspects assessed on each learner are different. This difference is due to the lack of a scoring instrument that is used as a benchmark; the teacher has not developed a technical skills assessment instrument on specific web programming practices in a particular subject matter that measures the skills in the lab in detail; some teachers only develop technical assessment tools of technical skill aspects that are common to all practical materials, whereas the technical skill skills of the web programming practice between the subject matter are different; and the available assessment instruments have not been accompanied by scoring guidelines so that assessment is inevitable from the assessment of the appraisal. The technicall skill assessment is shared directly by the teacher or assessor. Therefore, in order to avoid subjective judgment which is often doubtful of its validity and reliability, it is used the assessment rubric as a reference in assessing student performance [8]. To obtain valid assessment results, assessment instruments are required as assessment tools. In a performance appraisal, the assessment instrument used as a guide in scoring is the rating rubric. According to Rashid \& Mansur [9], the rubric basically contains a list of criteria embodied with performance dimensions, aspects or concepts to be as sessed along with the gradation of quality from the most perfect to the most imperfect.

Several studies related to as sessment in productive subjects were conducted by Rizar [10] who stated that productive subject teachers had difficulty in developing learning programs up to the assessment of learning outcomes. A study conducted by Yulina [11] regarding the development of performance appraisal instruments reveals that the use of valid and reliable performance appraisal instruments can reveal student performance, the use of performance appraisals in laboratory activities is able to clearly demonstrate the criteria and demonstrate the level of competence that students have, and the use of performance appraisal in practicum activities can assess students' performance skills during the practicum process.

Technical skills are the ability to apply specific knowledge, methods, or techniques in a particular field of specialization. The technical skills assessment instrument has significance for the success of web programming learning because it can diagnose students' skill in doing practicum correctly and accurately. In this study the skills that must be mastered by students that are competence in web programming, Competence is the ability or competence that must be achieved by students as learners. In learning, students must be able to achieve the competencies that have been determined. When students are able to achieve these competencies, it can be said that students are able to master the subject matter and succeed in learning. Here are basic web programming skills, 1) presenting text; (2) present table; (3) presenting the display of multimedia formats; (4) presenting link format; and (5) presents the form. The material on these basic competencies is related to other competence materials so that students must be able to master each competence to be able to continue the next material competence. To be able to know the achievement of each student in each competence need the existence of report and observation at the time of learning process of practicum through the elaboration of aspect and criterion on the instrument of assessment of tecnical skill. Translation of aspects and criteria that exist in the assessment instrument allows teachers and students to know aspects that have not mastered by students so that there is need for improvement and improvement in the lab

Based on the issues described and the relevant research above, the researcher wants to develop a technical assessment instrument of specific web programming skill that measures the skills in the lab in detail, test the feasibility of the prototype of assessment instrument that can be used to measure the skill of technical skill of SMK student on lab web programming, knowing the user's response to the prototype of the student skill assessment instrument on the developed web programming practicum, examining the effectiveness of the prototype of the student skill assessment instrument on the developed web programming practicum. Thus, it is necessary to develop a psycho- $\neg$ ᄀtorage aspect assessment instrument on a web programming practice as an effort to achieve the objectives of the assessment activity, ie to provide students with valid, objective, and comprehensive information on the ability of the students. Based on the background of the problems that have been described, the researchers are interested in conducting research with the title "Development of Technical Skills Assessment Instrument on Student Web Programming Practices SMK".

\section{RESEARCH METHOD}

This research is a development research that focused on product development in the form of student appraisal instrument on web programming practice. The development design in this research uses $\mathrm{R} \& \mathrm{D}$ development model (research and development). The model consists of four stages of development, ie define, design, develop, and desseminate, or adapted into $4 \mathrm{P}$ models, defining, designing, developing, and disseminating [12]. The defining stages include curriculum analysis activities, material analysis, competency analysis, and assessment instrument analysis on web programming practice. The design stage involves designing specification of product design that begins by arranging lattice problem, composing problem, and composing the answer key. The development stage included product creation activities ie technicall assessment tools of web programming skills and continued on product validation by an expert team, limited testing, and field trials.

The subjects consist of all students of class $\mathrm{X}$ at SMKN 6 Malang, SMKN 3 Malang, and SMKN 11 Malang, along with 
teachers who teach productive subjects web programming at each school which amounts to 9 people. The study population is 300 students. The samples of the study were taken using Purposive Sampling technique (purposive sampling technique) used if the researcher had certain consideration and adjusted with main consideration [13]. where the students who have grade average grade are almost the same and the students who get the material of web programming are determined as the sample of the research, so that the sample number of 90 students is obtained.

Data were obtained from interviews, expert validation, user response questionnaire, web programming skills test, and post test. The data obtained through the validation sheet is used to assess the quality of the developed product. Qualitative data are responses, suggestions, or inputs from expert and practitioner teams compiled and summarized for product improvement. Reliability of test and product reliability is calculated by the alphacronbach formula. The effectiveness of the instrument can be seen from the skill improvement calculated by the $\mathrm{T}$ test formula [14]. The experimental design used pretest-posttest control group design, in both groups preceded by pretest, and after posttest treatment was performed.

\section{RESULT AND DISCUSSION}

The results of the feasibility study of the establishment of rice bran chicken noodle stall are starting from the market aspect, technical aspects, management aspects, financial aspects, legal aspects and environmental aspects as follows .

\section{A. Development of Technicall Skill Assessment Instruments}

The assessment instruments developed in this study are technical skills assessment guides, student worksheets, questions and assessment rubrics. the development of assessment instruments that will be carried out covers the defining, define, design and development. The result of developing the technical skill assessment instrument is the defining phase of the initial and final analysis to find out the basic problem faced for the next solution. In this analysis conducted interview activity of class $\mathrm{X}$ web programming teacher. Based on interview result it can be concluded that technicall skill assessment on a psychomotor aspect which is a technique in assessing student skill still not done by the teacher. Student analysis is conducted with the aim to know the competencies that have and must be owned by students. Student analysis is done by analyzing the students' skills that should be assessed in the assessment column in the syllabus of web programming subjects. the results of the analysis obtained that the assessment of students when the lab includes several skills, among others, (1) presents the text; (2) present table; (3) presenting the display of multimedia formats; (4) presenting link format; and (5) presents the form. Conceptual analysis is conducted with the aim to detail the concept of the material by means of assessment. conceptual analys is is done by analyzing the material, learning, and assessment in the syllabus. Web programming material is chosen because almost all schools carry out basic web programming practice. Task analysis aims to identify the main skills that will be studied by researchers. This analysis ensures a thorough review of the tasks in the learning materials, and the specification of instructional objectives is derived from the general-purpose translation of web programming written on the SMK syllabus.

The design stage of the preparation of products is made in the form of technical skills assessment instruments, while the aspects considered in the assessment guidelines are material, construction, and language. The selection of the products made is expected to be used to as sess students' technical skills on web programming practicum, therefore the format of the assessment product should be clear and detailed the technical assessment tools of web programming skills developed systematically complemented by usage instructions, scoring guidelines, student worksheets basic, learning objectives, basic theory, tools, and how to work lab), as well as questions and rubrics assessment assessment format determined by the author in the form of books to facilitate the storage and not easily lost and damaged. therefore in the product there is also cover, introduction, and table of contents and bibliography.

\section{B. Feasibility of technicall skill assessment instruments (Development Phase)}

Product assessment instrument development is validated by three validators. The instrument used in data collection is a questionnaire. The first validation (draft I) was performed by two expert validators and one practitioner, including validation of technical skill assessment instruments consisting of student worksheets and assessment rubrics. The results of the instrumentality validity analys is are summarized in Table 1.

TABLE I. INSTRUMENT VALIDATION RESULTS IN TECHNICAL SKILL RATING

\begin{tabular}{|c|c|}
\hline Validator & Result \\
\hline I & 91,67 \\
\hline II & 93,75 \\
\hline III & 100 \\
\hline Average & 95,14 \\
\hline
\end{tabular}

Based on the calculation results, the result of expert validator I $91.67 \%$, expert validator II $93.75 \%$, and $100 \%$ practitioner validator with the number of 12 statements to obtain the average validation result is $95.14 \%$. Based on the average results obtained, instruments included in valid criteria with descriptions may be used with minor revisions.

A limited trial was conducted on 10 students of class X RPL 1 SMKN 6 Malang. Limited trials were conducted in three meetings. The activities of learners during the learning process practicum on web programming materials are assessed by using assessment instruments. This limited trial aims to determine the agreement between the rater (Percented Agreement) and the instrument reliability value.

Reliability of assessment instruments used by three raters. Each rater observes the skills of the learner. The use of this rater aims to find the value of assessment instrument reliability developed. The third rater assesses the web programming skills of learners for three meetings using a rating scale. Skill score 
of the test result is calculated its reliability value using interrater reliability analysis. This calculation uses the help of the SPSS program by looking at the Cronbach Alpha value. The results of the instrument reliability analysis are summarized in Table 2.

TABLE II. RESULT OF RELIABILITY ANALYSIS INSTRUMENT EVALUATION TECHNICAL SKILL

\begin{tabular}{|c|c|}
\hline Instrumen & Cronbach Alpha \\
\hline I & 0,813 \\
\hline II & 0,623 \\
\hline III & 0,818 \\
\hline Average & 0,751 \\
\hline
\end{tabular}

Based on the calculation results obtained Cronbach Alpha value on an instrument I of 0.813 , on Instrument II of 0.623 , and Instrument III of 0.818. Based on the calculations, the assessment of the web programming practice included in the category of good reliability. This field trial is a step measurement of web programming skills of learners using the instrument assessment of technical skills that have been valid and reliable. The product is then used to measure the skills of the learners.

\section{The effectiveness of technicall skills assessment instruments}

Skills measurements were conducted at SMKN 6, SMKN 3, and SMKN 11 Malang involving 30 students in each class, 3 meetings or 3 basic competencies, and a total of 90 students. On field trials involving 9 observers or teachers. The $\mathrm{T}$ test results are presented in Table 3 .

TABLE III. TEST RESULT OF SMKN 6 MALANG

\begin{tabular}{|c|c|c|c|c|c|c|}
\hline \multicolumn{2}{|c|}{ Group } & Mean & $\mathbf{t}_{\text {hitung }}$ & Db & Sig. & Information \\
\hline \multirow[b]{2}{*}{ Pretest } & Control & 62,37 & \multirow[b]{2}{*}{0,582} & \multirow[b]{2}{*}{58} & \multirow[b]{2}{*}{0,563} & \multirow{2}{*}{$\begin{array}{l}\text { Not } \\
\text { significantly } \\
\text { different }\end{array}$} \\
\hline & Experiment & 61,33 & & & & \\
\hline \multirow[b]{2}{*}{ Posttest } & Control & 76,93 & \multirow{2}{*}{$\begin{array}{l}- \\
2,693\end{array}$} & \multirow{2}{*}{58} & \multirow{2}{*}{0,009} & \multirow{2}{*}{$\begin{array}{l}\text { Significantly } \\
\text { different }\end{array}$} \\
\hline & Experiment & 80,07 & & & & \\
\hline \multirow{2}{*}{$\begin{array}{l}\text { Gain } \\
\text { score }\end{array}$} & Control & 14,57 & \multirow[b]{2}{*}{$\overline{2,893}$} & \multirow[b]{2}{*}{58} & \multirow[b]{2}{*}{0,005} & \multirow{2}{*}{$\begin{array}{l}\text { Significantly } \\
\text { different }\end{array}$} \\
\hline & Experiment & 18,73 & & & & \\
\hline
\end{tabular}

In a comparison of posttest value between control and experiment group obtained significance value equal to 0,009 . Because the significance value is smaller than the real level of 0.05 , it can be concluded that there is a difference of posttest value between Control group and Experiment group where experiment group average is higher than the control group. Thus, it can be said that giving treatment gives the effect that can increase sample score. The T-Test Result of SMKN 3 is presented in Table 4.
TABLE IV. TEST RESUlt OF SMKN 3 MALANG

\begin{tabular}{|c|c|c|c|c|c|c|}
\hline \multicolumn{2}{|c|}{ Group } & Mean & $\mathbf{t}_{\text {hitung }}$ & db & Sig. & Information \\
\hline \multirow{2}{*}{ Pretest } & Control & 63,37 & \multirow{2}{*}{0,329} & \multirow{2}{*}{58} & \multirow{2}{*}{0,743} & \multirow{2}{*}{$\begin{array}{l}\text { Not } \\
\text { significantly } \\
\text { different }\end{array}$} \\
\hline & Experiment & 62,77 & & & & \\
\hline \multirow{2}{*}{ Posttest } & Control & 78,33 & \multirow{2}{*}{-} & \multirow{2}{*}{58} & \multirow{2}{*}{0,001} & \multirow{2}{*}{$\begin{array}{l}\text { Significantly } \\
\text { different }\end{array}$} \\
\hline & Experiment & 82,00 & & & & \\
\hline \multirow{2}{*}{$\begin{array}{l}\text { Gain } \\
\text { score }\end{array}$} & Control & 14,97 & \multirow{2}{*}{-} & \multirow{2}{*}{58} & \multirow{2}{*}{0,025} & \multirow{2}{*}{$\begin{array}{l}\text { Significantly } \\
\text { different }\end{array}$} \\
\hline & Experiment & 19,23 & & & & \\
\hline
\end{tabular}

In a comparis on of posttest value between Control and Experiment group obtained significance value equal to 0,001 . Because the significance value is smaller than the real level of 0.005 it can be concluded that there are differences in posttest values between the Control group and the Experiment group in which the experimental group average is higher than the control group. Thus, it can be said that giving treatment gives the effect that can increase sample score. The $\mathrm{T}$ test results of SMKN 11 are presented in Table 5.

TABLE V. TEST RESUlt OF SMKN 11 MALANG

\begin{tabular}{|c|c|c|c|c|c|c|}
\hline \multicolumn{2}{|c|}{ Group } & Mean & $\mathbf{t}_{\text {hitung }}$ & db & Sig. & Information \\
\hline \multirow[b]{2}{*}{ Pretest } & Control & 63,73 & \multirow[b]{2}{*}{1,218} & \multirow[b]{2}{*}{58} & \multirow[b]{2}{*}{0,228} & \multirow{2}{*}{$\begin{array}{l}\text { Not } \\
\text { significantly } \\
\text { different }\end{array}$} \\
\hline & Experiment & 61,50 & & & & \\
\hline \multirow[b]{2}{*}{ Posttest } & Control & 77,53 & \multirow{2}{*}{$\begin{array}{l}- \\
2,888\end{array}$} & \multirow[b]{2}{*}{58} & \multirow[b]{2}{*}{0,005} & \multirow{2}{*}{$\begin{array}{l}\text { Significantly } \\
\text { different }\end{array}$} \\
\hline & Experiment & 81,20 & & & & \\
\hline \multirow{2}{*}{$\begin{array}{l}\text { Gain } \\
\text { score }\end{array}$} & Control & 13,80 & \multirow{2}{*}{ - } & \multirow{2}{*}{58} & \multirow[b]{2}{*}{0,005} & \multirow{2}{*}{$\begin{array}{l}\text { Significantly } \\
\text { different }\end{array}$} \\
\hline & Experiment & 19,70 & & & & \\
\hline
\end{tabular}

On the comparison of posttest value between Control and Experiment group obtained significance value equal to 0,005 . Because the significance value is smaller than the real level of 0.05 , it can be concluded that there is a difference of posttest value between Control group and Experiment group where experiment group average is higher than the control group. Thus, it can be said that giving treatment gives the effect that can increase sample score.

In field trials, teachers/observers fill out a user response questionnaire. Questionnaire of user/teacher response is used to find out teacher's response or response to technical skill assessment instrument on web programming practice. Observer/teacher consists of 3 observers SMKN 6 Malang, 3 observers SMKN 3 Malang, and 3 observers SMKN 11 Malang. The following is the average of complete user response results presented in Table 6 . 
TABLE VI. Field Test Results (TEAcher Response)

\begin{tabular}{|c|c|c|c|}
\hline No & Aspect & Average & Category \\
\hline 1 & Material & 91,67 & Very good \\
\hline 2 & Construction & 85,00 & Very good \\
\hline 3 & Language & 86,67 & Very good \\
\hline 4 & Objectivity & 83,33 & Very good \\
\hline 5 & Systematic & 87,50 & Very good \\
\hline 6 & Practicability & 85,00 & Very good \\
\hline
\end{tabular}

Table 6 shows the average score for the material aspect is 91.67 with the "Good" category, the construction aspect obtains an average of 85.00 with the category "Very Good", and the language aspect earns an average of 86.67 with the category "Very Good". The average score for the objectivity aspect was 83.33 with the "Good" category, the systematic aspect earned an average of 87.50 with the category of "Very Good", and the practiceability aspect earned an average of 85.00 with the category of "Very Good".

\section{DISCUSSION}

First, this research produces a systematic programmatically developed programming practice assessment instrument and comes with instruction manuals, scoring guides, student worksheets (basic competencies, learning objectives, theoretical basis, tools, and work practices), and assessment questions and rubrics. The products developed by the technical skills assessment instrument will go through individual testing stages, limited trials, and field trials. In the defining stages the results of the interviews show that the assessment of technical skills in practical activities is conducted in groups. This is not in accordance with the theory [15] which states that the assessment of aspects of psychomotor conducted in the form of group assessment is not in accordance with the essence of learning. Learning outcomes are reflected in changes in student behavior. Therefore, although students learn in groups in one class, learning outcomes and abilities are always individuals [16]. Based on the explanation, the assessment of learning outcomes is more appropriate to be done individually to provide an accurate and objective learning outcomes and objective student abilities.

The results of the interviews also show that the assessment instrument used is not supplemented by the gradation of quality expressed by score and performance description on each score. Assessment of the psychomotor aspect is a subjective assessment done, that is only based on teacher observation or assessment of individual behavior. Therefore, the existence of a clear reference to assess psychomotor ability is necessary. It can be fulfilled with the use of rubrics as a benchmark assessment that is able to reveal students' psychomotor abilities at various levels. The use of rubrics can also ensure reliability, fairness, and correctness of the judgment. This is in line with Law Number 66 The year 2013 on Education Assessment Standards which states that the assessment of psychomotor capabilities included in the skills competency assessment in the Curriculum 2013 can be done using a checklist or rating scale with a rubric. Assessment can be done at the time the process takes place that is when the students do the practice, or after the process takes place by testing the students [17]. The above discussion shows the need for the development of technical skills assessment instruments on web programming practice.

Based on the results of requirement analysis, the web programming material becomes the material that will be developed in the assessment instrument. Furthermore, core competence analysis and basic competence of web programming are done by elaborating the basic competence into learning indicators. In accordance with the submateri and aspects of ability to be assessed, then the learning indicators selected to be a reference in determining the learning objectives in the next stage of learning indicators on basic competencies. Based on the results of learning indicators, the specification of learning objectives is done. The purpose of learning is basically a formulation of the forms of behavior that will have students after following the learning process. The format of writing the formulation of learning objectives includes basic competencies and learning objectives that form the basis in preparing the grid of assessment instruments. The use of lattice questions can help teachers in decision-making related to the preparation of the test. The grid questions can also improve the validity of the evaluation by teachers in the preparation of classroom tests [18].

Preparation of tests on student worksheets and test questions are used to measure students' mastery or ability through certain predetermined criteria [19]. In the development of assessment instruments, the measurement of students' abilities is derived from aspects of the assessment or criteria contained in the assessment instrument. Preferred media is a pratikum worksheet or student worksheet. The worksheet is chosen because it contains a question or work command questions or work orders that require students to bring the ability in the form of real action. This is in accordance with [20] which states that the student worksheets are sheets of material, summaries, and tasks to be done by learners. The use of student worksheets can also guide and direct students when practicum activities are not dominated by teacher instruction. It is in accordance with the main purpose of the media to streamline the process of learning of communication so as to achieve the desired goals [21]. The tool used is also a supporting component in web programming practice activities. The next step is the selection of a format that serves to set the display of assessment instruments. The format of the assessment instrument is divided into three stages of activity, namely opening, execution, and closing. At the beginning of the drafting, the assessment instrument consists of an assessment aspect in the form of an observation sheet containing scores and as sessment of aspects of each score. The observation sheet contains the student identity, the assessment aspect divided into three stages of the practicum, and the column for the given score. Assessment aspect is the formulation of a statement of the assessment indicators 
contained in the grid. While the as ses sment column contains an assessment score range of $0-4$.

Determination of assessment aspects to be assessed begins with a look at the problem or work orders contained on the student worksheet and identify skills aspects. Working questions or orders require observable student performance. The performances are then identified to determine the skills, ie skills that must be mastered by students in a practicum that is technical skills skill. Skills are formulated in the form of clearly defined statement expressions. The sentence is an aspect of the assessment that states the performance aspect to be judged or referred to as the criterion.

Preparation of criteria on assessment instruments based on the sequence of questions or work orders contained on the student worksheet. It aims to facilitate the teacher or assessor in the assessment because students' technical assessment is done by observing directly the performance of students. Furthermore, the assessment aspect that has been determined is determined by quality using the quality of the assessment. Assessment quality is a storied or graded quality performance that is expressed with a score with a certain range and a performance description at each level of score. The score range used is $0-4$. In the last stage of the initial design. At this stage the preparation of student worksheets and assessment instruments. Student worksheets contain practical questions and assessment rubrics that teachers use to assess students. According to [22], Rubrik actually facilitates the teacher in doing the assessment because with a rubric, the teacher can assess the students. This is reinforced by the statement [23], with the assessment rubric, the teacher becomes more objective and accurate in assessing student learning outcomes. After the design, then carried out the development stage to improve the assessment instrument and find out the user response to the assessment instrument developed. At the development stage, there are four activities including validation, limited trial, field test (effectiveness test).

Second, the validator's assessment of the assessment instruments developed includes material, construction and language aspects. after validation, there are revisions made by researchers. In accordance with the validator's suggestion, revisions are made to the writing and content of the product. This revision is done to produce better products in terms of writing and content. During the validation process, the researcher receives many suggestions from the validator on all parts of the assessment instrument. The most widely shared suggestions relate to grammar and image representation, aspects of practice, performance score and descriptions, and completeness of as ses sment instruments. During validation, the researcher receives many suggestions from expert evaluation evaluators and practitioners on all parts of the assessment instrument. The most widely shared suggestions relate to grammar, grammar, and completeness of assessment instruments. The most improvement is made on the completeness of assessment instruments. Based on the validator's suggestion, the assessment instrument comes with cover, introduction, table of contents, introduction (general guidance), assessment guide, and bibliography. This is done to facilitate teachers or users in understanding and using assessment instruments for wider use. The front cover contains the title of the rating instrument, the author's name, and the image representing the contents of the assessment instrument. The general guidance is briefly explained for the purpose of using and applying the instruments of assessment to the learning activities. In the instrument of assessment also described specific instructions on the use of instruments that explain in detail the manner of use. In addition, it also comes with assessment guidelines as a reference for users or teachers in processing the assessment results. This is in line with the research conducted by Suaib [24] which explains that content validation is used to assess the compatibility between the measuring instrument (test) and the measured goal. According to Usman [25], in order for the assessment instrument to get a good criterion, it will be revised based on suggestion, correction and consideration of validator and researcher. After the revision of this tool can be used in assessing the performance of the lab

In the material aspect, the validator gives the category very well because the material is something that the teacher presents to be processed then understood by the students [26]. In the material aspect contains a statement of conformity of the material with basic competence, kesesusaian matter with the material, and conformity with the rubric assessment of the web programming. This is supported by research [27], which states that the dish in the skills assessment instrument in accordance with the Competency Standards (SK) and Basic Competence (KD), the indicators are in line with SK-KD, the questions on instruments and symbols which are used in accordance with the concept, overall the skills assessment instrument has the appearance and content of appropriate learning so that it can be used to as sess the students' skills. Based on the above opinion, it can be concluded that the learning material is the content that will be given to the students in the learning process. Learning materials will lead students to the goals to be achieved in learning.

In the construction aspect, the validator gives excellent category because the construction of technical skill as sessment instruments is equipped with clear drawings and clues in doing practical work and scoring. The media of images is a media that combines facts and ideas clearly [28]. Interesting construction aspects make students very fond of student worksheets created by researchers. In addition, the command questions are also complete with information that must be done students at the time of the lab. This is supported by research [29] which states that the construction feasibility aspect is very good. It shows that the rubric of objective assessment assesses the students' skills in learning.

In the language aspect, the validator gives a very good category because the language used in the assessment instrument is a familiar and easily understood language. This is supported by research [30] that the language aspects of sentence structure used in each item of practice observation sheet in accordance with good and correct Indonesian rules.

Reliability of assessment instruments using the formula "Alpha Cronbach". Computer-assisted calculation of SPSS 
program. Reliability is used to view the rater agreement in assessing students of limited testing hasi student competence values obtained from third-rater/observer. Results of the reliability value are $0.75 \%$, so it can be concluded that the assessment instruments in the reliability category of "good". This is supported by research [31] which states that the evaluation instrument lab has a very high level of reliability in terms of reliability $0,80-1,00$ value criteria. This value is explained that the practical assessment instruments have a level of regularity or consistency in delivering the measurement and assessment of all aspects of student competence in practical web programming. According to Fika [32] The value of the reliability of the test and non-test also revealed reliable before it is used so that the skills proved to have a positive influence on the achievement of learning outcomes.

Third, the effectiveness test is obtained from the calculation of the increase of posttest score of the students in the three schools, namely in SMKN 6, SMKN 3, and SMKN 11. The students' competence score has increased on average. This is due to the influence of the use of technical valuation valuation skills on web programming practice. By looking at the assessment criteria in the rubric, students can know the criteria of the learning outcomes that must be achieved in the competence. The clarity of these learning demands can encourage student progress. From the calculation of the average obtained, it is known that there is increasing mastery of web programming material after treatment. In the experimental class, the analysis with the average technique obtained the result that the final ability of the experimental group that received treatment of 80.00 SMKN 6 Malang, 82.00 SMKN 3 Malang, and 81.20 SMKN 11 Malang. While the mean of control class is 76,93 SMKN 6 Malang, 78,33 SMKN 3 Malang, and 77,53 SMKN 11 Malang. The results of the data calculations show a significant difference between the control class and the experimental class. Thus, it shows that learning by using an effective assessment instrument in improving students' mastery of competence in web programming. This is supported by research [33] which states that in the psychomotor domain, learners get value above the KKM so that learners are included in the skill category and authentic assessment can measure the level of achievement of students' competence in the affective, cognitive, and psychomotor aspects. In addition, according to [34], students have been skilled in performing process performance and product performance. It proves that there are no students who have the poor psychomotor ability, this is because in practice process using assessment instrument to measure psychomotor aspect and According [35], the use of practicum assessment can achieve students' learning mastery. The results of this study indicate that the assessment rubrics developed can be used as one of the guidelines for assessing student skills.

Teacher responses were analyzed through teacher response response scores filled out by teachers. the teacher's response questionnaire contains the statement you want to measure. The score shows the level of user response to the developed technical skill assessment instrument. The higher the score indicates that the teacher responds well to the technical skill assessment instruments made. The statement in the user / teacher response questionnaire contains material, construction, language, objectivity, systematic, and practical aspects. From the results of user responses, scores obtained at SMKN 6 Malang, SMKN 3 and SMKN 11 Malang showed a positive response from web programming teachers. From the questionnaire results, the assessment of the material aspects got a very good category. The results show that the assessment instrument is in accordance with the objectives of learning. It can be seen from the percentage of compliance statement about/instruction with the aim of learning that gets very good percentage compared to another statement on material aspect. In the construction aspect, it is found that the percentage of the category is "very good". The results indicate that the assessment instrument meets the requirements of construct validity. The percentage results in this aspect are in line with research conducted by Mega [36] that the results on the construction aspect are very good, this is because of the conformity of the procedures with task and suitability of task and rubric. Aspects of language get a very good category. This shows that the use of language is in accordance with the Indonesian language is good and correct according to the Enhanced Spell (EYD) and is concise and clear Ekawati \& Sumaryanta [37]. That's because in the preparation, the language used is adjusted to the level of development of student age so that is communicative and easy to understan

In the aspect of objectivity get a very good percentage, The percentage results on the aspect of objectivity is also presented in Luki's previous research in his research that states the objectivity aspect is used to see the validity and content and constructs on the assessment instrument. This is in line with research conducted by Nurjanah [38] which states that the percentage of objective aspects have good value because the assessment instrument can assess and provide information about the psychomotor ability of students accurately and accurately. In the systematic aspect, the category of "very good" is obtained. The results show that the preparation of assessment aspects in accordance with the practice and psychomotor domain. This is evidenced by the high percentage in the second statement on the systematic aspect. The results also indicate that the assessment instrument is in accordance with the criteria of rubric quality, ie the indicators in the rubric are sorted by the sequence of work steps on the task or systematic work of learners. The results are in line with the research conducted by Sela [39] with the percentage of categories of systematic aspects are very good, because in the systematic aspects can describe and formulate regularly and logically, so that the assessment instrument can be used to assess all aspects of the assessment. On the aspect of the practice obtained very good category. According to Arifin [40], practicality is the ease of the test, both in terms of preparing, using, processing, interpreting, and administer it. The excellent category in this aspect shows that the assessment instrument is easy to use by observers as well as with other users. This occurs because the assessment instrument is accompanied by student identity columns, assessment rubrics, 
user manuals, and scoring guidelines to make it easier for observers or teachers to administer, score, use, and interpret the assessment results. This is supported by Nur [41] study which states that practicality is analyzed through teacher response result data on performance appraisal tool, technical skill assessment tool in learners that have been developed can be practically used in learning. Based on the results of questionnaires, teacher responses are positive for students' technical skill assessment instruments. This happens because of the guidance of instruments that can facilitate teachers in using the instrument and there are rubrics that contain criteria or indicators of achievement of achievement of learning results so as to facilitate the teacher in providing assessments and help students in understanding the target learning.

\section{CONCLUSION}

First, the development of this research using 4D model, which is define, design, develop, and dissemenate. The material used in this research is class $\mathrm{X}$ web programming practice with the following basic competence: (1) present text in certain format on web page; (2) present the table on the web page; (3) presents the display of multimedia formats on web pages; (4) presenting link format on web page; and (5) presents the form on the web page. This technical skill assessment instrument contains usage instructions, assessment steps, and a web programming assessment instrument consisting of six basic competencies. Each basic competency includes user manuals, scoring guidelines, student student worksheets, and as sessment rubrics.

Second, the feasibility of the result of the validator assessment indicates that the technical skills assessment instrument is valid or feasible at every point of observation developed. The overall validator's assessment states that the technical skills assessment instrument on the web programming practice is feasible to be used for field trials with appropriate revisions. In the limited trial stage, the value of web programming practice skills is obtained. Reliability of assessment instruments was analyzed with inter rater reliability shown by Cronbach Alpha values. The reliability of the assessment instrument is included in the "good" reliability category.

Third, field trials aim to find out an increase in student learning outcomes that use technical assessment instrument skills. In addition, at this stage also aims to determine the user's response to the technicall skills assessment instruments. The results of the data calculations show significant differences in control and experiment class learning outcomes. In the experimental class, the analysis with the average technique obtained the result that the final ability of the experimental group that received treatment of 80.00 SMKN 6 Malang, 82.00 SMKN 3 Malang, and 81.20 SMKN 11 Malang. While the mean of control class is 76,93 SMKN 6 Malang, 78,33 SMKN 3 Malang, and 77,53 SMKN 11 Malang. Questionnaire user response consists of nine web programming teachers. The instrument of students' technical skill assessment on web programming practice gets user percentage percentage of $84.47 \%$ with "excellent" category. Based on the explanation it can be said that the product development instrument as ses sment is valid, effective, feasible to use, and can improve student skills.

Suggestion: First, Web Programming teachers are advised to apply technical assessment instrument products to develop students' skills on other web programming materials. Second, the technical assessment instrument product of this development skill is suggested to be maximally utilized by the web programming teacher as a guide to developing technical skill assessment. Third, teachers really pay attention to the meaning of each score to be given to all assessment indicators achieved. Fourthly, when using this rubric, teachers should perform prior stimulation to the students by providing information about the most important skills that will be assessed so that these skills can be raised

\section{REFERENCES}

[1] Azim, S. \& Khan, M. 2012. Authentic Assessment: An Instructional Tool to Enhance Students Learning. The American Journal of Distance Education. ISSN, 2 (3): 314

[2] Gaytan, J. \& McEwen, B. 2007. Effective Online Instructional and Assessment Strategies. The American Journal of Distance Education, 21 (3): 118 .

[3] Hofstein, A. \& Lunetta, V.N. 2004. The Laboratory for Science Education: Foundations for the Twenty-First Century. Wiley Periodicals, Inc. Sci, 88 (1): 28-54.

[4] Firman, H. 2013. Evaluasi Pembelajaran Kimia. Bandung: Jurusan Pendidikan Kimia. FMIPA UPI

[5] Wisconsin Education Association Council. 1996. Performance Assessment, Education Issues Series.

[6] Iskandar, A. 2011. Penilaian Kinerja, (Online), (http://akbariskandar.blogspot.com/2013/05/penilaian-kinerja.html, diakses 30 Maret 2016).

[7] Susila, I Ketut. 2012. Pengembangan Instrumen Penilaian Unjuk Kerja (Performance Assesment) Laboratorium Dalam Pembelajaran Fisika Sesuai Kurikulum Tingkat Satuan Pendidikan SMA Kelas X di Kabupaten Gianyar. UNDIKSHA. (Online), (http://pasca.undiksha.ac.id/e-journal/index.php, diakses 20 Januari 2016).

[8] Zainul, A. 2001. Alternative Assessment. Jakarta: Universitas Terbuka.

[9] Rasyid, H., \& Mansur. 2009. Penilaian hasil belajar. Bandung: CV Wacana Prima.

[10] Rizar, A. 2014. Implementasi Penilsian Hasil Belajar Kurikulum 2013 Pada Program Keahlian Teknik Audio Video Di SMK Surakarta.. Tesis tidak diterbitkan.Yogyakarta: Pendidikan Teknik Mekatronika, Universitas Negeri Yogyakarta.

[11] Yulina.E. 2014. Instrumen Penilaian Kinerja Untuk Menilai Kompetensi Psikomotorik Siswa SMA Pada Materi Hidrolisis Garam. Tesis tidak diterbitkan. Bandung : Pascasarjana Universitas Pendidikan Indonesia.

[12] Trianto.2014. Mendesain model pembelajaran inovatif, progresif, dan kontekstual. Jakarta: Prenadamedia Group.

[13] Mukhadis, A. 2016. Metode Penelitian Kuantitatif Bidang Pendidikan Dan Contoh Aplikasinya. Malang:Aditya Media Publishing.

[14] Sudjana. 2005.Penilaian Hasil Proses Belajar Mengajar. Bandung: PT. Remaja Rosdikarya.

[15] Dimyati \& Mudjiono. 2006. Belajar dan Pembelajaan. Jakarta: Rineka Cipta.

[16] Hakiim,L.2009. Perencanaan Pembelajaran. Bandung : Wacana Prima.

[17] Nurwati, A. 2014.Penilaian Ranah Psikomotorik Siswa Dalam Pelajaran Bahasa. Jurnal Penelitian Pendidikan. 9(2): 1-10. 
[18] Mushoffa. 2014. Telaah Soal Uji Coba I Bahasa Indonesia di SMP Kabupaten Wonosobo Tahun 2013. Diksi. 22(2): 153-164.

[19] Sukardi. 2012. Evaluasi Pendidikan. Jakarta: Bumi Aksara.

[20] Anggraeni, R. 2016. Pengembangan Lembar Kerja Siswa (Lks) Berbasis Keterampilan Proses Di SMAN 4 Jember. Jurnal Pembelajaran Fisika. 4(4): 350-356.

[21] Munadi, Y. 2012. Media Pembelajaran. Jakarta: Gaung Persada (GP). Press.

[22] Anson, C. 2012. Big Rubrics and Weird Genres: The Futility of UsingGeneric Assessment Tools AcrossDiverse Instructional Contexts. The Journal of Writing Assessmen. 5(1): 1-19.

[23] Comer, K. 2009. Developing Valid and Reliable Rubrics for Assessment. Research and Practice. Good Practice Publication Grants: Nasional Centre for Tertiary Teaching Excellence.

[24] Suaib, M. 2013.Pengembangan Instrumen Penilaian Microsoft Word Pada Mata Pelajaran Teknologi Informasi Dan Komunikasi Di Sekolah Menengah Pertama. Makalah disajikan dalam Seminar Nasional Implementasi Kurikulum 2013.

[25] Usman, H. 2015. Pengembangan Perangkat Penilaian Kinerja Praktikum Fisika Pada Peserta Didik SMP. Jurnal Ilmiah Pendidikan Fisika. 1(1): 1 11.

[26] Nana \& Ibrahim. 2003.Perencanaan Pengajaran. Jakarta: PT. Rineka Cipta.

[27] Mustika, N, A. 2014.Pengembangan Instrumen Penilaian Keterampilan Metakognisi Pada Pembelajaran IPA di SMP. Skripsi tidak diterbitkan. Bandar Lampung: Universitas Lampung.

[28] Sudjana. 2007. Media Pengajaran. Bandung: Sinar Baru Algesindo.

[29] Wati.W.2016. Pengembangan Rubrik Asesmen Keterampilan Proses Sains Pada Pembelajaran IPA SMP. Jurnal Ilmiah Pendidikan Fisika. 05 (1): 131-140

[30] Budhiwaluyo, N. 2015. Pengembangan Instrumen Penilaian Kinerja pada Praktikum Struktur dan Fungsi Sel. Jurnal Education Sains. 5(2): 1-8.

[31] Sanjaya, E. 2016. Pengembangan Instrumen Evaluasi pada Praktikum Uji Enzim Katalase di SMA Negeri Titian Teras Muaro Jambi. Journal EduSains. 4(2): 1-8.

[32] Fika, N. 2014. Pengembangan Instrumen Penilaian Keterampilan Berpikir Kritis Siswa SMA.

[33] Rusdiana, H. 2014. Evaluasi Hasil Belajar Menggunakan Penilaian Autentik Pada Mata Pelajaran Kelistrikan Sistem Refrigerasi. Journal Of Mechanical Engineering Education. 1(2): 274-283.

[34] Karlina. 2014. Pengembangan Instrumen Penilaian Aspek Psikomotorik Pada Percobaan Kromatografi Kolom. Jurnal Pedidikan Kimia. 2(1): 1-7.

[35] Puspitasari, N. 2014.Pengembangan Rubrik Performance Assessment Pada Praktikum Hidrolisis Garam. Jurnal Inovasi Pendidikan Kimia. 8(1): $1250-1259$

[36] Mega, L. 2016.Pengembangan Instrumen Asesmen Kinerja Pada Praktikum Sistem Dan Lingkungan. Thesis tidak diterbitkan. Bandar Lampung: Universitas Lampung.

[37] Luki, Y. 2016. Pengembangan Instrumen Penilaian Aspek Psikomotorik Siswa SMA/MA Pada Praktikum Titrasi Asam Basa. Skripsi tidak diterbitkan.Jakarta: Uin Syarif Hidayatullah.

[38] Nurjanah, S. 2013.Pengembangan Instrumen Penilaian Psikomotorik IPA. Skripsi tidak diterbitkan.Yogyakarta: Universitas Islam Negeri Sunan Kalijaga.

[39] Sela. 2016. Pengembangan Instrumen Penilaian Aspek Psikomotor Siswa Pada Praktikum Termokimia . Skripsi tidak diterbitkan. Jakarta: Universitas Islam Negeri Syarif Hidayatullah.

[40] Arifin, Z. 2011. Evaluasi pembelajaran. Bandung: PT Remaja Rosdakarya.

[41] Nur, S. 2015. Pengembangan Instrumen Asesmen Kinerjakimia Berbasis Asesmen Otentikdengan Estimasi Reliabilitasnya menggunakan Program Genova. Tesis Tidak diterbitkan. Semarang: Universitas Negeri Semarang. 